\title{
Valorisation of Phosphorus-Saturated Constructed Wetlands for the Production of Sugarcane
}

\author{
Dina Mateus ${ }^{1,2, *}$, Mafalda Vaz ${ }^{1}$ and Henrique Pinho ${ }^{1,3}$ \\ ${ }^{1}$ Instituto Politécnico de Tomar, Unidade Departamental de Engenharias, Campus da Quinta do Contador, \\ Estrada da Serra, 2300-313 Tomar, Portugal \\ ${ }^{2}$ GEOBIOTEC - Geobiociências, Geoengenharias e Geotecnologias, Universidade de Aveiro, Portugal \\ ${ }^{3}$ CERENA - Centro de Recursos Naturais e Ambiente, Universidade de Lisboa, Portugal
}

\begin{abstract}
Constructed wetlands $(\mathrm{CW})$ are a clean and environmentally friendly alternative to conventional wastewater treatment methods, namely in the removal of the nutrients responsible for the eutrophication of receiving water bodies, as is the case of phosphorus compounds. The materials used as CW filling can directly contribute to the removal of phosphorus compounds from wastewater, but with the operating time they tend to become saturated and treatment efficiency decreases. In order to evaluate the viability of producing an energy crop in phosphorus-saturated CW, sugarcane growth was monitored in two pilot-scale CW filled with two different expanded clay aggregates used for 10 years in wastewater treatment. This paper presents the results obtained during the first year of plant development in the plant-cane cycle. Morphologic aspects of sugarcane growth, such as height and average diameter of stems, average leaf area and number of new sprouts, have been monitored. The results obtained are comparable with those cited in the literature for traditional cultivation. Dry biomass productivity of 26.6 ton per hectare per year can be achieved. Estimated sucrose productivity can reach 13.5 ton per hectare per year, and related bioethanol production potential can be between 2.4 and 7.6 cubic meters per hectare per year, depending on the CW filter media used. It is concluded that the cultivation of sugarcane in CW allows to extend the life of these systems by reusing fillers, and simultaneously is an alternative to produce bioethanol raw-material without the use of scarce resources such as arable land, fresh water and plant nutrients.
\end{abstract}

Keywords: Bioethanol, expanded clay, phosphorous removal, sustainability, wastewater treatment.

\section{INTRODUCTION}

Sugarcane is the most important feedstock for large-scale production of bioethanol fuel, particularly in tropical and sub-tropical countries where crop productivity is high and agricultural costs are low [1-4]. Bioethanol obtained from sugarcane may represent a potential reduction of $80 \%$ of $\mathrm{GHG}$ emissions relative to gasoline, while bioethanol derived from maize may represent only up to $52 \%$ reduction in GHG emissions [5].

The production of bioethanol from sugarcane juice or molasses has the advantage of being a welldeveloped and implemented technology, but crop production may require large arable land areas and scarce resources as fresh water and nutrients such as phosphorous compounds [6-8].

Constructed wetlands (CW) are an ecological and sustainable alternative to conventional wastewater treatment systems, especially for nutrient removal. CW consist of beds, usually dug into the ground, sealed and filled with filter materials, and planted with

*Address correspondence to this author at the Department of Engineering, Instituto Politécnico de Tomar, Estrada da Serra, Quinta do Contador, 2300313 Tomar, Portugal; Tel: 351249328 160; Fax: 351249328 167;

E-mail: dinamateus@ipt.pt macrophyte plants $[9,10]$. Wastewater treatment occurs as it passes through the beds by a complex variety of interacting biological, chemical and physical processes. The two main types of CW are free surface or subsurface flow. For sanitary reasons, the subsurface flow is most frequently used because there is no direct contact between the wastewater and the atmosphere [9]. The effectiveness of these systems depends, besides correct dimensioning, on the selection of a filling material with high pollutant-removal capacity and good hydraulic characteristics, as well as the selection of plants species suitable for growing in flooded beds.

Filling materials represent the largest portion of initial capital investment of constructed wetlands. Therefore, its selection is crucial to the viability of these systems and should be based on performance, availability, safety and cost criteria. Although there are many studies on the feasibility of using industrial byproducts or natural filling materials, such as limestone fragments, ceramic waste, slag from iron and steel industries, among others [11-13] that are sustainable alternatives because of their cost-effectiveness, the use of various types of expanded clays produced specially for this purpose is very common due to their high efficiency [11, 14, 15]. However, expanded clays are a relatively expensive material. Therefore, the 
possibility of regeneration and/or subsequent use as a substrate for growing valuable crops, for example, is an asset and enhances sustainability of the plants using this type of filling material.

Reed (Phragmites australis) is one of the most commonly used macrophytes in $\mathrm{CW}$, due to its high pollutant removal capacity and high resistance to extreme environmental conditions [9]. However, the possibility of growing sugarcane instead of traditional macrophytes has been confirmed in previous studies $[16,17]$ and enhances the sustainability of such wastewater treatment technology through the production of sucrose-rich vegetable biomass, which could be used to produce bioethanol through widely implemented processes. At the same time, the production of this energy crop in CW would avoid the use of agricultural lands and water consumption, as well as the diversion of raw materials from the food supply chain, constraints often referred to in the development of biofuel production [18]. Thus, this study presents data concerning the re-utilisation of $\mathrm{CW}$ filled with expanded clay, previously used for phosphorus removal from wastewater, to simultaneously produce bioethanol feedstock (sugarcane) and to perform wastewater treatment.

\section{MATERIALS AND METHODS}

\subsection{Materials}

Two pilot scale CW were built in an inner courtyard of the campus of the Polytechnic Institute of Tomar (Central Portugal, 39³5'57.7' N, 8²3'26.1”'W) under the conditions of a Mediterranean climate, classification Csa according to the Köppen-Geiger climate classification [19]. They consist of rectangular PVC tanks above the soil surface $(1.2 \mathrm{~m}$ long $\times 1.0 \mathrm{~m}$ wide $\mathrm{x}$ $0.53 \mathrm{~m}$ deep) with a slope of $1 \%$ and a drainage system composed by two longitudinal perforated pipes at the bottom. Each tank contains a first $0.10 \mathrm{~m}$ layer of gravel that covers the drainage system, and a second $0.37 \mathrm{~m}$ layer of expanded clay Filtralite (Maxit Portugal), with Filtralite ${ }^{\circledR}$ MR 3/8 (CW-MR; round, 500 to 600 $\mathrm{kg} / \mathrm{m}^{3}, 3$ to $8 \mathrm{~mm}$ ) and another with Filtralite ${ }^{\circledR} \mathrm{NR} 3 / 8$ (CW-NR; round, $300 \mathrm{~kg} / \mathrm{m}^{3}, 3$ to $8 \mathrm{~mm}$ ). Filtralite ${ }^{\circledR} \mathrm{MR}$ has higher density than Filtralite ${ }^{\circledR}$ NR, shows better capabilities for wastewater treatment but is more expensive [15].

The CW have been in operation for about 10 years as phosphorus filters without plants, in a continuous vertical subsurface flow mode. In May, six plants of the
Saccharum officinarum species (sugarcane) with 3month germination have been transferred to each tank. Plants were selected at a similar stage of development and planted about $0.15 \mathrm{~m}$ deep, following a $2 \times 3$ distribution with equal interspacing, in both beds. The experiments were conducted without any pre-treatment of the filler materials and with no addition of fertilizers or pesticides.

\subsection{Sugarcane Growth Monitoring}

The sugarcane plants were monitored regularly until late November. Stalk diameter was measured at the first internode from each stalk base. Stalk height was measured from the bottom of the canes near the surface of the filler material to the base of leaf +1 (first well-developed leaf counted from the plant's top).

The number of fully-expanded green leaves for each plant was counted and the length and width of the leaf +3 measured (third well-developed leaf counted from the plant's top). Average plant's leaf area was estimated using the model proposed by Silva et al. [20].

\subsection{Biomass Productivity}

In November the sugarcanes with about 10 months' growth were cut and biomass yield and sucrose content of the stalks determined. Above-ground biomass was harvested, separated into stalk and leafs and the fresh weight of stalks was measured. Representative samples of plant stems were finelychopped using a cutter-grinder, and dried at $60{ }^{\circ} \mathrm{C}$ to constant weight to evaluate the dry matter content.

Wet and dry basis biomass annual productivity was estimated on a per hectare basis, considering the fresh biomass measured and dry matter content calculated in each CW divided by CW superficial area multiplied by a scale factor of 1.5. The scale factor was used to take into account the extra area required for the movement of personnel and machinery in a real scale CW.

\subsection{Sugarcane Sucrose Content and Bioethanol Production Potential}

Sucrose production was estimated according to the correlation proposed by Muchow et al. [21], which correlates sucrose accumulation in the sugarcane stalk with crop biomass, on a dry weight base.

Bioethanol potential production was estimated from the sucrose to ethanol conversion of 0.570 cubic meters of ethanol by metric ton of processed sugar, 
which value corresponds to the lower end of the usual conversion range for modern ethanol production facilities [22].

Sugarcane and bioethanol productivities were converted to annual values per hectare as for biomass productivity calculations.

\subsection{Constructed Wetland Performance Evaluation}

Total Phosphorus (TP) removal in CW was monitored between January and November. During this period the CW were fed continuously with secondary wastewater effluent, at the hydraulic load average of $41 \pm 2 \mathrm{Lm}^{-2}$ day $^{-1}\left(0.041 \mathrm{~m}^{3} \mathrm{~m}^{-2}\right.$ day $\left.^{-1}\right)$ with average concentrations of TP of $8.2 \pm 1.9 \mathrm{mg} / \mathrm{L}\left(1 \mathrm{mg} / \mathrm{L}=10^{-3}\right.$ $\mathrm{kg} / \mathrm{m}^{3}$ ), total nitrogen (TN) of $14 \pm 6 \mathrm{mg} / \mathrm{L}$ and $\mathrm{COD}$ of $20 \pm 10 \mathrm{mg} / \mathrm{L}$.

Every two weeks, samples were collected at input and output CW streams and analysed to determine the concentration of TP. Analysis followed standard methods for the examination of water and wastewater [23]. $5 \mathrm{~mL}$ water samples were autoclaved in an acid potassium persulfate solution at $121{ }^{\circ} \mathrm{C}$ for $30 \mathrm{~min}$. After digestion and cooling, liberated orthophosphates were quantified spectrophotometrically at $880 \mathrm{~nm}$, by ascorbic acid method.

\section{RESULTS AND DISCUSSION}

\subsection{Sugarcane Growth Indicators}

Figure 1 presents the sugarcane average height in the two pilot-scale $\mathrm{CW}$ during the growth period, compared to sugarcane growth in traditional soil irrigated cultures [20]. The sugarcane height growth was weaker than the one observed for soil cultures, following the same trend until the seventh month of growth. Growth evolution was significantly better for sugarcanes planted in the CW-NR $(P<0.001)$.

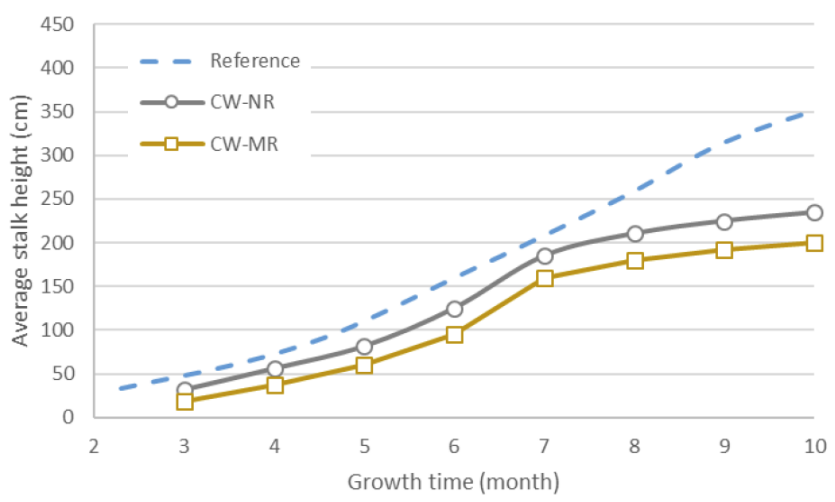

Figure 1: Average sugarcane stalk height growth. The dashed line represents typical sugarcane stalk height growth in soil plantations [20].
Figure 2 presents the average stalk diameter of sugarcane in the two pilot-scale CW during the growth period, compared to sugarcane growth in traditional soil irrigated cultures [20]. After a lower growth at first months, CW sugarcane growth was better than the one observed for soil cultures. Diameter evolution was significantly better for sugarcanes planted in the CW$N R(P=0.012)$.



Figure 2: Average sugarcane stalk diameter growth. The dashed line represents typical sugarcane stalk diameter growth in soil plantations [20].

Table 1 shows the average dimensions of the sugarcanes at the time of cutting (10 months). All biometric indicators are better for plant growth in CW$N R$, but not significantly different for average height and average diameter $(P=0.244$ and $P=0.850)$, and with low significance for the average foliar area $(P=0.046)$.

Although the average final stalk height was lower than the one reported by Silva et al. [20], Figure 1, experimental values are within the range reported in the literature for sugarcane with equal growth time, between 1.18 and $2.22 \mathrm{~m}[24,25]$.

The average stalk diameters obtained in both $\mathrm{CW}$ are superior to those reported by Silva et al. [20] and also by Caione et al. [25], located between 0.0218 and $0.0220 \mathrm{~m}$.

Average foliar areas observed in both $\mathrm{CW}$ are above the range reported in the literature, between 0.166 and $0.600 \mathrm{~m}^{2} /$ plant $[26,27]$.

\subsection{Biomass Production and Bioethanol Production Potential}

Table 2 shows the indicators of sugarcane productivity in both $\mathrm{CW}$. Although sugar content is higher for the canes in CW-MR, productivity in terms of fresh biomass and sucrose is about three times lower 
Table 1: Average Dimensions of the Cane Stems and Leaves at Cutting Time. Confidence Intervals were Estimated with a Level of Confidence of $95 \%$

\begin{tabular}{|c|c|c|c|}
\hline Pilot-Scale CW & $\begin{array}{c}\text { Average Stalk Height } \\
(\mathbf{m})\end{array}$ & $\begin{array}{c}\text { Average Stalk Diameter } \\
\left(\mathbf{1 0 ^ { - 3 }} \mathbf{~ m}\right)\end{array}$ & $\begin{array}{c}\text { Average Foliar Area } \\
\left(\mathbf{m}^{2} / \text { Plant }\right)\end{array}$ \\
\hline \hline CW-NR & $2.35 \pm 0.69$ & $29 \pm 7$ & $1.0 \pm 0.1$ \\
\hline CW-MR & $2.00 \pm 0.23$ & $28 \pm 2$ & $0.7 \pm 0.1$ \\
\hline
\end{tabular}

Table 2: Estimated Productivity Indicators for Sugarcane Production in the CW. Units Typical in Sugarcane Industry: 1 ton $/ \mathrm{ha} \cdot$ Year $=0.1 \mathrm{~kg} / \mathrm{m}^{2}$ Year; $1 \mathrm{~m} / \mathrm{ha} \cdot$ Year $=10^{-4} \mathrm{~m}^{3} / \mathrm{m}^{2}$ Year)

\begin{tabular}{|c|c|c|c|c|}
\hline Pilot-Scale CW & $\begin{array}{l}\text { Biomass Wet Basis } \\
\text { (ton/ha. Year) }\end{array}$ & $\begin{array}{l}\text { Biomass Dry Basis } \\
\text { (ton/ha.Year) }\end{array}$ & $\begin{array}{c}\text { Sucrose } \\
\text { (ton/ha·Year) }\end{array}$ & $\begin{array}{c}\text { Bioethanol } \\
\left(\mathrm{m}^{3} / \mathrm{ha} \cdot \text { Year }\right)\end{array}$ \\
\hline CW-NR & 105 & 26.6 & 13.3 & 7.6 \\
\hline CW-MR & 33 & 8.4 & 4.2 & 2.4 \\
\hline
\end{tabular}

than for CW-NR. This difference is due to the fact that in the CW filled with Filtralite ${ }^{\circledR}$ NR the canes showed a better development (cf. Table 1) and produced more new sprouts.

Biomass yield are within the range of results published for conventional culture which, depending on the cultivation conditions, can vary between 30 and 226 tons per hectare per year, wet basis [28, 29]. Bioethanol productivity of traditional sugarcane plants ranges from 7 to 8 cubic meters per hectare per year $[30,31]$. So, estimated productivity of CW-NR is well within the range of reference, whereas productivity of CW-MR is far below the commercial range.

The feasibility of using $\mathrm{CW}$ vegetation to produce bioethanol by biomass fermentation after cellulose hydrolysis was assessed by $\mathrm{He}$ et al. 2010 [32]. For the common CW vegetation Phragmites australis these researchers obtained a yield of $0.01 \mathrm{~kg}$ of ethanol per $\mathrm{kg}$ of dry plant biomass. Considering the typical Phragmites australis productivity in $\mathrm{CW}$ of up to 1.8 $\mathrm{kg} / \mathrm{m}^{2}$, the estimated potential of bioethanol production may be calculated as 0.23 cubic meters per hectare per year $[33,34]$. Although this route also represents a sustainable production of bioethanol, the productivity is expressively lower than sugarcane bioethanol and requires a not yet well-developed lignocellulose conversion technology.

\subsection{Phosphorus Removal Efficiency of the Constructed Wetland}

Special attention was dedicated to phosphorous removal capabilities of sugarcane planted $\mathrm{CW}$ due to the importance of phosphorous compounds on water bodies eutrophication problems. Average TP removal efficiencies were $44 \pm 12 \%$ for CW-NR and $50 \pm 9 \%$ for CW-MR. The values obtained for phosphorus removal are within the range of values found in the literature for the macrophyte based CW, ranging between $38 \%$ and $99 \%$ [9].

Although the expanded clays were already saturated in phosphorus, it was found that the growth of sugarcane allowed these materials to be reused as $\mathrm{CW}$ filling materials for wastewater treatment, thus prolonging their lifetime.

\section{CONCLUSIONS}

It can be concluded that sugarcane can be produced in CW saturated filling media, extending the lifetime of expanded clays applied in wastewater treatment.

Growth biometrics of sugarcane plants in $\mathrm{CW}$ conditions is comparable to growth of plants in traditional lands. Growth indicators and productivity of sugarcane was different for the two tested filling media. Growth indicators were better and productivity was higher for sugarcane growth in Filtralite $\AA$ NR than in Filtralite $\AA$ MR, which is more expensive.

Estimated bioethanol productivity is 7.6 and $2.4 \mathrm{~m}^{3}$ per CW hectare per year, respectively for Filtralite $₫$ NR and Filtralite $\AA$ MR fillings. The higher value is in the range of typical productivities for traditional ethanol production from sugarcane. Besides the lower value obtained for the Filtralite ${ }^{\circledR}$ MR filling, sugarcane production on this filling media represents an improvement in the sustainability of CW technology. 
In addition to demonstrating the feasibility of producing a first-generation bioethanol feedstock, the results showed that the growth of sugarcane in exhausted filter media ensures $\mathrm{CW}$ wastewater treatment capabilities and contributes to reducing the use of arable land and the consumption of scarce resources such as fresh water and phosphorus, among other nutrients used as fertilizers in traditional sugarcane production.

\section{ACKNOWLEDGEMENTS}

The authors acknowledge Isabel Silva and Alcino Serras from IPT's Chemical and Environmental Technical Lab for helpful technical assistance and Fátima Paiva for paper proofreading.

\section{REFERENCES}

[1] Cardona CA, Sánchez ÓJ. Fuel ethanol production: Process design trends and integration opportunities. Bioresour Technol 2007; 98: 2415-57. http://dx.doi.org/10.1016/j.biortech.2007.01.002

[2] Fischer G, Teixeira E, Hizsnyik ET, van Velthuize $H$. Land use dynamics and sugarcane production. In: Zuurbier $\mathrm{P}$, van de Vooren J, editors. Sugarcane ethanol production: Contributions to climate change mitigation and the environment. Wageningen, The Netherlands: Wageningen Academic Publishers 2008; pp. 29-62.

[3] Waclawovsky AJ, Sato PM, Lembke CG, Moore PH, Souza GM. Sugarcane for bioenergy production: An assessment of yield and regulation of sucrose content. Plant Biotechnol J 2010; 8: 263-76. http://dx.doi.org/10.1111/j.1467-7652.2009.00491.x

[4] Hess TM, Sumberg J, Biggs $T$, et al. A sweet deal? Sugarcane, water and agricultural transformation in SubSaharan Africa. Glob Environ Change 2016; 39: 181-94. http://dx.doi.org/10.1016/i.gloenvcha.2016.05.003

[5] Souza GM, Victoria RL, Verdade LM, et al. Bioenergy numbers. In: Souza GM, Victoria RL, Joly CA, Verdade LM, editors. Bioenergy \& sustainability: Bridging the gaps. Paris: Scientific Committee on Problems of the Environment 2015; pp. 28-57.

[6] Inman-Bamber NG, Smith DM. Water relations in sugarcane and response to water deficits. Field Crops Res 2005; 92: 185-202.

http://dx.doi.org/10.1016/j.fcr.2005.01.023

[7] Costa ARFC, Rolim MM, Bonfim-Silva EM, Neto DES, Pedrosa ERM, Silva ÊFF. Accumulation of nitrogen, phosphorus and potassium in sugarcane cultivated under different types of water management and doses of nitrogen. Aust J Crop Sci 2016; 10: 362-9. http://dx.doi.org/10.21475/ajcs.2016.10.03.p7205

[8] Albuquerque AW, Sá LA, Rodrigues WAR, Moura AB, Filho MSO. Growth and yield of sugarcane as a function of phosphorus doses and forms of application. Rev Bras Eng Agríc Ambient 2016; 20: 29-35. http://dx.doi.org/10.1590/1807-1929/agriambi.v20n1p29-35

[9] Kadlec $\mathrm{RH}$, Wallace SD. Treatment Wetlands, $2^{\text {nd }}$ ed. Boca Raton: CRC Press 2009.

[10] Wu H, Zhang J, Ngo HH, et al. A review on the sustainability of constructed wetlands for wastewater treatment: Design and operation. Bioresour Technol 2015; 175: 594-601. http://dx.doi.org/10.1016/j.biortech.2014.10.068
[11] Vohla C, Kõiv M, Bavor HJ, Chazarenc F, Mander Ü. Filter materials for phosphorus removal from wastewater in treatment wetlands - A review. Ecol Eng 2011; 37: 70-89. http://dx.doi.org/10.1016/j.ecoleng.2009.08.003

[12] Mateus DMR, Vaz MMN, Pinho HJO. Fragmented limestone wastes as a constructed wetland substrate for phosphorus removal. Ecol Eng 2012; 41: 65-9.

http://dx.doi.org/10.1016/j.ecoleng.2012.01.014

[13] Haynes RJ. Use of industrial wastes as media in constructed wetlands and filter beds - Prospects for removal of phosphate and metals from wastewater streams. Crit Rev Environ Sci Technol 2015; 45: 1041-103. http://dx.doi.org/10.1080/10643389.2014.924183

Albuquerque A, Oliveira J, Semitela S, Amaral L. Evaluation of the effectiveness of horizontal subsurface flow constructed wetlands for different media. J Environ Sci 2010; 22: 820-25. http://dx.doi.org/10.1016/S1001-0742(09)60183-2

[15] Mateus DMR, Pinho HJO. Phosphorus removal by expanded clay - Six years of pilot-scale constructed wetlands experience. Water Environ Res 2010; 82:128-37. http://dx.doi.org/10.2175/106143009X447894

[16] Mateus DMR, Vaz MMN, Capela I, Pinho HJO. Sugarcane as constructed wetland vegetation: Preliminary studies. Ecol Eng 2014; 62: 175-78

http://dx.doi.org/10.1016/j.ecoleng.2013.10.031

[17] Mateus DMR, Vaz MMN, Capela I, Pinho HJO. The potential growth of sugarcane in constructed wetlands designed for tertiary treatment of wastewater. Water 2016; 8(93): 1-14. http://dx.doi.org/10.3390/w8030093

[18] Food and Agriculture Organization of the United Nations. The State of Food and Agriculture. Rome: Electronic Publishing Policy and Support Branch, Communication Division, FAO; 2008.

https://doi.org/10.1201/9781420012514

[19] Kottec M, Grieser J, Beck C, Rudolf B, Rubel F. World map of the Köppen-Geiger climate classification updated. Meteorol Z 2006; 15: 259-63. http://dx.doi.org/10.1127/0941-2948/2006/0130

[20] Silva TGF, Moura MSB, Zolnier S, Carmo JFA, Souza LSB. Biometria da parte aérea da cana soca irrigada no Submédio do Vale do São Francisco (Biometrics of the sugar cane shoot during irrigated ratoon cycle in the Submedio of the Vale do São Francisco). Rev Ciênc Agron 2012; 43: 500-9. http://dx.doi.org/10.1590/S1806-66902012000300012

[21] Muchow RC, Robertson MJ, Wood AW, Keating BA. Effect of nitrogen on the time-course of sucrose accumulation in sugarcane. Field Crops Res 1996; 47: 143-53. http://dx.doi.org/10.1016/0378-4290(96)00022-6

[22] Lavarack BP. Estimates of ethanol production from sugar cane feedstocks. In: Hogarth DM, editor. Proceedings of the Conference of the Australian Society of Sugar Cane Technologists; 2003: Townsville, Queensland: Australian Society of Sugar Cane Technologists 2003; p. 69. Available from:

https://www.assct.com.au/media/pdfs/2003_pa_m25.pdf

[23] Rice EW, Baird RB, Eaton AD, Clesceri, Eds. Standard Methods for the Examination of Water and Wastewater, 22nd ed. Washington: American Public Health Association, American Water Works Association, Water Environment Federation 2012

[24] Santos VR, Filho GM, Albuquerque AW, Costa JPV, Santos $\mathrm{CC}$, Santos ACl. Crescimento e produtividade agrícola de cana-de-açúcar em diferentes fontes de fósforo (Growth and yield of sugarcane under different phosphorus sources). Rev Bras Eng Agríc Ambient 2009; 13: 389-96. http://dx.doi.org/10.1590/S1415-43662009000400004

[25] Caione G, Lange A, Benett C, Fernandes F. Fontes de fósforo para adubação de cana-de-açúcar forrageira no cerrado (Phosphorus sources for sugarcane forage cultivars 
fertilization in the Brazilien Savannah). PesquiAgropecu Trop 2011; 41: 66-73

http://dx.doi.org/10.5216/pat.v41i1.8497

[26] Robertson MJ, Wood AW, Muchow, RC. Growth of sugarcane under high input conditions in tropical Australia. I. Radiation use, biomass accumulation and partioning. Field Crops Res 1996; 48: 11-25.

http://dx.doi.org/10.1016/0378-4290(96)00041-X

[27] Farias $\mathrm{C}$, Neto J, Fernandes $\mathrm{P}$, Gheiy $\mathrm{H}$. Índice de área foliar em cana-de-açúcar sob diferentes níveis de irrigação e zinco na Paraíba (Leaf are a index of sugarcane under different levels of irrigation and zinc in Paraiba State). Revista Caatinga 2007; 20 (4): 45-55. Available from: https://periodicos.ufersa.edu.br/index.php/sistema/article/vie w/45/235

[28] Agostinho F, Ortega E. Integrated food, energy and environmental services production as an alternative for small rural properties in Brazil. Energy 2012; 37: 103-14. http://dx.doi.org/10.1016/j.energy.2011.10.003

[29] Maqsood M, Iqbal M, Tayyab M. Comparative productivity performance of sugarcane (Saccharum officinarum L.) sown in different planting patterns at farmer's field. Pak J Agric Sci 2005; 42(3-4): 25-8. Available from: http://www.pakjas.com. pk/papers/428.pdf
[30]

Hartmink AE. Sugarcane for bioethanol: Soil and environmental issues. In: Advances in agronomy, Volume 99. Sparks DL, editor. London: Academic Press 2008; pp. 12582.

http://dx.doi.org/10.1016/S0065-2113(08)00403-3

[31] Schaffel SB, La Rovere EL. The quest for eco-social efficiency in biofuels production in Brazil. J Clean Prod 2010; 18: $1663-70$.

http://dx.doi.org/10.1016/j.jclepro.2010.06.031

[32] He M, Hu Q, Zhu Q, Pan K, Li Q. The feasibility of using constructed wetlands plants to produce bioethanol. Environ Prog Sustain Energy 2015; 34: 276-81. http://dx.doi.org/10.1002/ep.11953

[33] Tanner CC. Plants for constructed wetland treatment systems - A comparison of the growth and nutrient uptake of eight emergent species. Ecol Eng 1996; 7: 59-83. http://dx.doi.org/10.1016/0925-8574(95)00066-6

[34] Zheng Y, Wang XC, Ge Y, Dzakpasu M, Zhao Y, Xiong J. Effects of annual harvesting on plants growth and nutrients removal in surface-flow constructed wetlands in northwestern China. Ecol Eng 2015; 83: 268-75.

http://dx.doi.org/10.1016/j.ecoleng.2015.06.035

Received on 31-01-2017

DOI: https://doi.org/10.6000/1929-6002.2017.06.01.1

(c) 2017 Mateus et al.; Licensee Lifescience Global.

This is an open access article licensed under the terms of the Creative Commons Attribution Non-Commercial License (http://creativecommons.org/licenses/by-nc/3.0/) which permits unrestricted, non-commercial use, distribution and reproduction in any medium, provided the work is properly cited. 